\title{
Moderasi Jumlah Komite Audit atas Pengaruh Pengungkapan Corporate Social Responsibility terhadap Nilai Perusahaan
}

\author{
Rafika Sari ${ }^{1)}$ \\ ${ }^{1)}$ Program Studi Akuntansi Fakultas Ekonomi, Universitas Indo Global Mandiri \\ Jalan Jenderal Sudirman No 629 KM 4 Palembang Kode Pos : 30129 \\ Email : rafikasari@uigm.ac.id ${ }^{l)}$
}

\begin{abstract}
The purpose of this study is to determine the moderation of the number of audit committees on the influence of Corporate Social Responsibility Disclosure on the value of the company on companies listed on the Indonesia Stock Exchange (BEI) during the period 2016. This study contributes to the social ethics literature in business. Theoretically, this research connects the relationship between these variables and empirically examines them. The results of the study show that there is a relationship between social aspects in a company with firm value, either partially or simultaneously. The data analysis method used is multiple linear regression. This method was chosen because the reference shows that there is a match between the analysis tool and the studied variable. The sample in this study uses random sampling with the solvin formula significant level of 5 percent so that the number of samples is 191 companies taken at random. The random sampling method was chosen because it is in accordance with the method of regression analysis. The results of the variable Corporate Social Responsibility (CSR) have a significant effect on Company Value in companies listed on the Indonesia Stock Exchange. Variable Number of Audit Committees (AC) is able to moderate the relationship of Corporate Social Responsibility (CSR) to Company Value (PER. The results of this study support the statement contained in agency theory and legitimacy that is the fulfillment of social responsibility to the environment able to provide positive externalities for the company and reduce problems conflict of interests and increase company value.
\end{abstract}

Keywords : Moderation in the Number of Audit Committees, Corporate Social Responsibility, Company Value

\begin{abstract}
ABSTRAK
Tujuan dari penelitian ini adalah untuk mengetahui moderasi dari jumlah komite audit atas Pengaruh Pengungkapan Corporate Socila Responsibility Terhadap nilai perusahaan pada perusahaan yang terdaftar di Bursa Efek Indonesia (BEI) selama periode 2016. Penelitian ini memberikan kontribusi terhadap literatur sosial etika dalam bisnis. Secara teoritis, penelitian ini menghubungkan hubungan antara variabel-variabel ini dan mengujinya secara empiris.Hasil penelitian menunjukan adanya hubungan antara aspek sosial dalam suatu perusahaan terhadap nilai perusahaan, baik secara parsial maupun simultan Metode analisis data yang digunakan adalah regresi linier berganda. Metode ini dipilih karena referensi menunjukan bahwa adanya kecocokan antara alat analisis dengan variabel yang diteliti.Sampel pada penelitian ini menggunakan random sampling dengan rumus solvin tingkat signifikan 5 persen sehingga jumlah sampel adalah 191 perusahaan yang diambil secara acak. Metode random sampling dipilih karena sesuai dengan metode analisis regresi. Hasil penelitian variabel Corporate Social Responsibility (CSR) memiliki pengaruh yang signifikan terhadap Nilai Perusahaan pada perusahaan yang terdaftar di Bursa Efek Indonesia. Variabel Jumlah Komite Audit (AC) mampu memoderasi hubungan Corporate Social Responsibility (CSR) terhadap Nilai Perusahaan (PER). Hasil penelitian ini mendukung pernyataan yang terdapat dalam teori agensi dan legitimasi yaitu pemenuhan tanggung jawab sosial terhadap lingkungan mampu memberikan eksternalitas positif bagi perusahaan dan mengurangi permasalahan konflik kepentingan dan meningkatkan nilai perusahaan.
\end{abstract}

Kata kunci : Moderasi Jumlah Komite Audit, Corporate Social Responsibility, Nilai Perusahaan 


\section{Pendahuluan}

Salah satu tujuan perusahaan didirikan adalah untuk meningkatkan nilai perusahaan. Setiap perusahaan tentunya menginginkan nilai perusahaan yang tinggi sebab hal tersebut juga secara tidak langsung menunjukkan kemakmuran pemegang saham juga tinggi. Nilai perusahaan yang tinggi dapat meningkatkan kemakmuran bagi pemegang saham, sehingga para pemegang saham akan menginvestasikan modalnya kepada perusahaan tersebut, (Cretu dan Brodie, 2007). Peningkatan nilai perusahaan yang tinggi merupakan tujuan jangka panjang yang seharusnya dicapai perusahaan, yang akan tercermin dari harga pasar sahamnya, karena penilaian investor terhadap perusahaan dapat diamati melalui pergerakan harga saham perusahaan (Anggraeni, 2013) dan investor biasanya mengamati harga laba yang diberikan dari peredaran saham yang ada untuk itu pada penelitian ini nilai perusahaan diukur dengan harga laba sahamnya (Price Earning Rasio)

Tren saat ini perusahaan tidak hanya dituntut untuk hanya memperoleh laba semata, namun juga etika perusahaan turut diamati oleh pihak steakholder , investor dan pemerintah perusahaan harus melihat lingkungan sekitarnya tanggung jawab perusahaan terhadap lingkunganya dianggap salah satu kewajiban yang harus dilakukan oleh perusahaan untuk mempertahankan kelangsungan usahanya, perusahaan yang memiliki tanggung jawab social (Corporate Social Responsibility)biasanya akan mengungkapkanya sebagai informasi kepada para steakholder, Pengungkapan Corporate Social Responsibility saat ini menggunakan standart internasional globart repoting initiative.

Mekanisme Corporate Governance juga menjadi sorotan para steakholder saat ini bagian dari mechanisme Corporate Governance salah satunya adalah keberadaan komite audit. Dengan adanya salah satu mekanisme GCG ini diharapkan dapat memonitoring terhadap manajer perusahaan dapat lebih efektif sehingga dapat meningkatkan kineja perusahaan dan nilai perusahaan.

Komite audit memiliki peran penting dalam menjaga akuntabilitas perusahaan. Komite audit bertugas mengawasi dan memantau sistem pelaporan keuangan perusahaan dan proses audit internal dan eksternal untuk menghindari asimetri informasi yang menjadi salah satu permasalahan dalam teori keagenan. Semakin banyak anggota dalam suatu komite audit akan mempengaruhi independensi dari komite audit, oleh sebab itu semakin banyak anggota komite audit maka akan menurunkan independensi komite audit dan akan berpengaruh terhadap kualitas laporan keuangan perusahaan juga dapat berpengaruh terhadap kualitas pengungkapan Corporate Social Responsibility (CSR) yang sesuai dengan standart yang diterapkan . Dengan begitu Komite Audit diharapkan mampu meningkatkan nilai perusahaan dan membantu pelaksanaan Good Coporate Governance (Anggraini, 2013). Hal ini sesuai ketentuan yang tertuang dalam Keputusan Nomor Bapepam LK. Kep 643 / BL / 2012 Tentang Penetapan Dan Pelaksanaan
Pedoman Komite Audit. Selain itu keberadaan dan independensi komite audit dapat mengurangi konflik kepantingan yang ada pada teori keagenan sehinggan hal tersebut dapat memperkuat pengaruh pengungkapan Corporate Social Responsibility (CSR) dalam meningkatkan nilai perusahaan dimata principal.

Beberapa penelitian terdahulu dengan topic yang sama dengan Hasil penelitian yang menyatakan adanya pengaruh yang signifikan corporate social responsibility terhadap nilai perusahaan yaitu penelitian (Bhuyan \& Perera 2017) (Etiasih,et al 2015)(Bayu, Putra, \& Wirakusuma, 2015)(Bulan dan Astika,2014); (Dagilienè,2013) dan (Rosiana, Juliarsa, \& Sari, 2013) dan (Servaes \& Tamayo, 2012), Sedangkan hasil penelitian yang menyatakan tidak adanya pengaruh yang signifikan corporate social responsibility terhadap nilai perusahaan yaitu penelitian(Gutsche, Schulz, \& Gratwohl, 2017); (Gherghina, dan Vintilă, 2016); (Putri, et al ,2016) (Kanwal et al, 2013); (Haryono \& Iskandar, 2015); (Kurniasari \& Warastuti, 2015)dan (Stacia dan Juniarti, 2013).

Berdasarkan Fenomena yang ada dan adanya research gap dalam penelitian sejenis maka peneliti tertarik untuk mengadakan penelitian dengan judul: "Pengaruh Pengungkapan Corporate Social Responsibility dan Jumlah Komite Audit Terhadap Nilai Perusahaan pada perusahaan yang terdaftar di Bursa Efek Indonesia“"

Adapun rumusan masalah dalam penelitian ini adalah "Bagaimana pengaruh pengungkapan Corporate Social Responsibility dan jumlah komite audit terhadap nilai perusahaan pada perusahaan yang terdaftar di Bursa Efek Indonesia (BEI) selama periode 2016? Tujuan dari penelitian ini adalah untuk mengetahui seberapa besar pengungkapan Corporate Social Responsibility dan jumlah komite audit berpengaruh terhadap nilai perusahaan pada perusahaan yang terdaftar di Bursa Efek Indonesia (BEI) selama periode 2016.

\section{Pembahasan}

\section{A. Landasan Teori}

1. Agency Theory

Masalah dasar dalam agency theory yaitu adanya konflik kepentingan atau konflik agensi. Teori Agensi menganalisis dan mencari solusi atas dua permasalahan yang muncul dalam hubungan antara "principal" (pemilik/pemegang saham) dan "agent" (manajemen puncak), yakni: 1) Agency problem muncul ketika (a) timbul konflik antara harapan atau tujuan pemilik/pemegang saham dan para direksi (top management), dan (b) para pemilik mengalami kesulitan untuk memverifikasi apa yang sesungguhnya sedang dikerjakan manajemen. 2) Risk sharing problem yang muncul ketika pemilik dan direksi memiliki sikap yang berbeda terhadap risiko (Surjadi dan Tobing, 2016).

Untuk kepentingan pemilik itulah komite audit dibentuk dan salah satu cara yang dapat dilakukan oleh pemilik untuk memastikan bahwa manajemen mengelola perusahaan dengan baik adalah dengan mekanisme 
corporate governance yang tepat. Dengan mekanisme corporate governance yang tepat diharapkan manajemen akan dapat memenuhi tanggung jawabnya sehubungan dengan kepentingan pemilik.Penelitian ini akan melihat solusi dari permasalahan agency teori, dimana Pengungkapan CSR yang transparan dan berdasarkan GRI versi 4 serta adanya komite audit akan mampu mengurangi biaya agency dan meningkatkan reputasi serta memaksimalkan nilai perusahaan.

2. Legitimacy Theory

Teori legitimasi menjelaskan bahwa sistem pengelolaan perusahaan berorientasi pada keberpihakan terhadap masyarakat. Teori legitimasi memfokuskan pada interaksi antara perusahaan dengan masyarakat. Sehingga tujuan metode operasi dan output organisasi harus sesuai dengan norma dan nilai sosial, legitimasi organisasi dapat dilihat sebagai sesuatu yang diberikan masyarakat untuk perusahaan dan sesuatu yang diinginkan atau dicari perusahaan dari masyarakat. Dengan demikian, legitimasi merupakan manfaat atau sumber daya potensial bagi perusahaan untuk bertahan hidup (going concern).

Teori ini menyatakan bahwa perusahaan dan komunitas sekitarnya memiliki relasi sosial yang erat karena keduanya terikat dalam suatu "social contract." Teori legitimasi menyatakan bahwa keberadaan perusahaan dalam suatu area karena didukung secara politis dan dijamin oleh regulasi pemerintah serta parlemen yang juga merupakan representasi dari masyarakat. Dengan demikian, ada kontrak sosial secara tidak langsung antara perusahaan dan masyarakat yang dalam hal ini masyarakat memberi cost dan benefits untuk keberlanjutan korporasi(Wahba \& Elsayed, 2015)

\section{B. Metode Penelitian}

Metode analisis data yang digunakan adalah regresi linier Metode ini dipilih karena referensi menunjukan bahwa adanya kecocokan antara alat analisis dengan variabel yang diteliti. Pengujian Pengolahan dan analisis data dalam penelitian ini dilakukan dengan menggunakan SPSS yang terdiri dari uji residual, uji asumsi klasik, dan uji hipotesis. Populasi penelitian ini adalah seluruh perusahaan yang terdaftar di Bursa Efek Indonesia (BEI) yang memenuhi kriteria populasi antara lain: 1) perusahaan yang terdaftar di Bursa Efek Indonesia sampai tahun 2016, 2) telah mempublikasikan d Annual Report tahun 2016, 3) memiliki nilai Price Earning Ratio (PER) yang positif.

Tabel 1. Rincian Kategori Populasi

\begin{tabular}{|l|c|}
\hline \multicolumn{1}{|c|}{ Keterangan } & Jumlah \\
\hline $\begin{array}{l}\text { Total Perusahaan Terdaftar } \\
\text { sampai Tahun 2016 }\end{array}$ & $\mathbf{5 2 9}$ \\
\hline $\begin{array}{l}\text { Perusahaan yang belum publikasi } \\
\text { annual report 2016 }\end{array}$ & $(51)$ \\
\hline $\begin{array}{l}\text { Perusahaan Memiliki Nilai EPS } \\
\text { Negatif }\end{array}$ & $(114)$ \\
\hline Total Populasi & $\mathbf{3 6 4}$ \\
\hline
\end{tabular}

Berdasarkan rincian kategori tersebut maka populasi dalam penelitian ini berjumlah 364 perusahaan. Dari populasi tersebut maka dapat ditentukan jumlah sampel yang akan diteliti dalam penelitian ini. Teknik pengambilan sampel menggunakan random sampling yaitu pemilihan sampel dengan acak, teknik pengambilan sampel tersebut adalah teknik yang lebih cocok dengan penelitian yang menggunakan analisis regresi berganda. Sampel dari penelitian ini adalah sebanyak 191 yang akan diambil secara acak dari populasi yang ada .

\section{Hasil Uji Penelitian}

1. Hasil Uji Hipotesis

Pengujian hipotesis dalam penelitian ini sebelumnya harus dilakukan terlebih dahulu analisis statistik terhadap data yang telah diperoleh sebelumnya.

2. Persamaan Regresi 1

Berikut ini adalah persamaan regresi 1:

$\mathrm{Y}=\mathrm{a}+\mathrm{b}_{1} \mathrm{CSR}+\varepsilon_{1}$

Hasil hipotesis untuk persamaan regresi 1 yang telah diolah dengan bantuan program SPSS dapat dilihat pada dua uji berikut ini:

3. Uji F

Hasil uji $\mathrm{F}$ dilakukan untuk melihat pengaruh secara simultan atau bersama variabel bebas yaitu Corporate Social Responsibility (CSR) dan komite audit (AC) terhadap nilai perusahaan (PER) pada perusahaan yang terdaftar di Bursa Efek Indonesia. Hasil uji F tersebut dapat dilihat pada tabel 2 berikut:

Tabel 2. Hasil Uji F

\begin{tabular}{ccccccc}
\hline $\mathbf{A N O V A}^{\mathbf{b}}$ & & & & & & \\
\hline & & Sum of Squares & $\mathrm{df}$ & Mean Square & $\mathrm{F}$ & Sig. \\
\hline 1 & Regression & 10443,647 & 1 & 10443,647 & 41,365 & $.000^{\mathrm{a}}$ \\
& Residual & 47718,276 & 189 & 252,478 & & \\
& Total & 58161,924 & 190 & & & \\
& & & & & & \\
\end{tabular}

a. Predictors: (Constant), Corporate Social Responsibility

b. Dependent Variable: Nilai Perusahaan

Dari tabel 2 di atas dapat dilihat bahwa $F_{\text {hitung }}$ yaitu sebesar 41,365 dengan nilai Sig. yaitu 0.000. Pengujian hipotesis dalam penelitian ini dengan membandingkan nilai $\mathrm{F}_{\text {hitung }}$ dan $\mathrm{F}_{\text {tabel }}$ taraf signifikansi yaitu 5\% sehingga didapat nilai $F_{\text {tabel }}$ yaitu sebesar 3,89. Berdasarkan hasil tersebut dapat dilihat bahwa nilai $F_{\text {hitung }}$ yaitu sebesar 41,365 lebih besar dari nilai $F_{\text {tabel }}$ yaitu sebesar 3,89 Artinya variabel independen yaitu Corporate Social Responsibility (CSR)) berpengaruh Signifikan secara simultan terhadap variabel dependen nilai perusahaan (PER) pada perusahaan yang terdaftar di Bursa Efek Indonesia

4. Hasil Uji T

Hasil uji t dilakukan untuk melihat pengaruh secara parsial atau sendiri variabel bebas yaitu Corporate Social Responsibility (CSR) pada perusahaan yang terdaftar di Bursa Efek Indonesia. Hasil uji t tersebut dapat dilihat pada tabel 3 berikut: 
Tabel 3. Hasil Uji $t$

\begin{tabular}{ll|c|c}
\hline \multicolumn{1}{c|}{ Model } & T & Sig. \\
\hline $1 \quad$ (Constant) & 2,133 & .003 \\
& Corporate Social Responsibility & 6,432 & .000 \\
& & \\
\hline
\end{tabular}

a. Dependent Variable: Nilai Perusahaan

Pengujian hipotesis dalam penelitian ini dilakukan dengan membandingkan nilai $t_{\text {hitung }}$ dan $t_{\text {tabel }}$. Dimana nilai $t_{\text {tabel }}$ berdasarkan $(\mathrm{df}=\mathrm{n}-2) \mathrm{df}=191-2$ yaitu 189 dan taraf signifikansi yaitu $5 \%$ sehingga didapat nilai $\mathrm{t}_{\text {tabel }}$ yaitu sebesar 1,652 Pada tabel 3 di atas dapat dilihat bahwa nilai $t_{\text {hitung dapat dijelaskan bahwa Corporate }}$ Social Responsibility (CSR) berpengaruh secara signifikan terhadap nilai perusahaan, ditunjukkan dengan nilai $t_{\text {hitung }}$ sebesar 2,133 yang lebih besar dari nilai $t_{\text {tabel }}$ yaitu sebesar 1,652 .

\section{Hasil Uji Interaksi Moderasi}

Pada persamaan regresi 2 dengan uji interaksi hasil hipotesis dapat dilihat yitu dengan meambandingkan hasil $\mathrm{R}$ squere dari persamaan satu dan Persamaan 2 dimana persamaan 1 adalah $\mathrm{Y}=\mathrm{Y}=\mathrm{a}+\mathrm{b}_{1} \mathrm{CSR}+\varepsilon_{1}$ dan Persamaan 2 adalah $=\mathrm{Y}=\mathrm{a}+\mathrm{b}_{1} \mathrm{CSR}+\mathrm{b}_{2} \mathrm{AC}+\mathrm{b}_{3}$ $\mathrm{CSR} * \mathrm{AC}+\varepsilon_{1}$ hasil terlihat pada tabel berikut

Tabel 4. Hasil Uji Interaksi Persamaan 1 Model Summary

\begin{tabular}{cc|c|c|c} 
Model & $\mathrm{R}$ & R Square & $\begin{array}{c}\text { Adjusted R } \\
\text { Square }\end{array}$ & $\begin{array}{c}\text { Std. Error of } \\
\text { the Estimate }\end{array}$ \\
\hline 1 & $.424^{\mathrm{a}}$ & .180 & .175 & $\begin{array}{c}15.889545380 \\
000000\end{array}$ \\
\hline
\end{tabular}

a. Predictors: (Constant), Pengungkapan CSR

Tabel 5. Hasil Uji Interaksi Persamaan 2 Model Summary

\begin{tabular}{cc|c|c|c} 
Model & R & R Square & $\begin{array}{c}\text { Adjusted R } \\
\text { Square }\end{array}$ & $\begin{array}{c}\text { Std. Error of } \\
\text { the Estimate }\end{array}$ \\
\hline 1 & $.454^{\mathrm{a}}$ & .206 & .193 & $\begin{array}{c}15.712832190 \\
000000\end{array}$ \\
\hline
\end{tabular}

a. Predictors: (Constant), CSR*AC, Jumlah Komite Audit, Pengungkapan CSR

Dari hasil uji interaksi kedua persamaan tersebut dapat dilihat nilai $\mathrm{R}$ squere pada persamaan 2 dapat dilihat pada table 5 lebih besar yaitu sebesar 0,180 dari pada pada persamaan 1 dapat dilihat pada table 4yaitu sebesar 0,206 artinya keberadaan komite audit mampu memoderasi atau memperkuat pengaruh pengungkapan corporate social responsibility terhadap nilai perusahaan.

\section{E. Pembahasan Hasil Penelitian}

1. Pengaruh Pengungkapan Corporate Social Responsibility Terhadap Nilai Perusahaan.
Pengungkapan Corporate Social Responsibility (CSR) merupakan akar dari pengakuan bahwa bisnis merupakan bagian dari masyarakat dan bahwa itu mempunyai potensi untuk membuat kontribusi yang positif untuk mencapai tujuan dan aspirasi sosial (Jones dan Comfort, 2005). Berdasarkan Hasil Pengujian Hipotesis Uji F Secara Simultan Pengungkapan Corporate Social Resposibility berpengaruh Positif dan signifikan terhadap nilai perusahaan.

Berdasarkan Hasil Uji T Secara Persial Corporate Social Responsibility (CSR) berpengaruh secara signifikan terhadap nilai perusahaan, ditunjukkan dengan nilai $t_{\text {hitung }}$ sebesar 2,133 yang lebih besar dari nilai $t_{\text {tabel }}$ yaitu sebesar 1,652. Hal ini membuktikan bahwa diindonesia fakta bahwa investor telah melihat nilai suatu perusahaan dengan memperhatikan aktifitas CSR yang diungkapan dalam laporan tahunan, ditahun 2016 tren dalam pengunkapan CSR yang berpedoman pada GRI 4 atau lebih dikenal dengan laporan berkelanjutan telah menarik minat berbagai pihak, karena pada laporan tersebut menyajikan item item tentang kelangsungan perusahaan saat ini dan dimasa yang akan datang juga kepedulian perusahaan terhadap lingkunganya. Berdasarkan hasil penelitian yang pernah dilakukan Latupono dan Andayani (2016) tentang analisis terhadap 30 perusahaan sappel dari tahun 2009 sampai dengan tahun 2011 (1) CSR berpengaruh signifikan terhadap nilai perusahaan dengan arah koefisien positif. Hal ini menunjukan bahwa semakin tinggi tingkat pengungkapan CSR yang dilakukan, maka nilai perusahaan akan semakin tinggi. Dengan adanya pengungkapan CSR, maka stakeholder akan memberikanapresiasi positif yang ditunjukkan dengan peningkatan harga saham perusahaan. Peningkatan ini akan menyebabkan nilai perusahaan meningkat. (2) Good corporate governance dengan proksi kepemilikan manajerial mampu mempengaruhi hubungan CSR dengan nilai perusahaan. Ini diartikan bahwa semakin besar good corporate governance maka semakin besar potensi untuk meningkatkan nilai perusahaan.

2. Moderasi Komite Audit Pada Pengaruh Pengungkapan Corporate Social Responsibility Terhadap Nilai Perusahaan

Berdasarkan hasil uji interaksi pada persamaan pertama dan kedua jumlah komite audit perusahaan dapat memoderasi dengan memperkuat pengaruh Corporate Social Responsibility dengan nilai perusahaan. Hal ini sejalan dengan teori agency dan legitimacy bahwa perusahaan yang memiliki komite audit sesuai standart akan memiliki pengungkapan CSR yang lebih besar dan berdampak pada tingginya nilai perusahaan..

\section{Kesimpulan}

Berdasarkan hasil analisis dan pembahasan pada bab sebelumnya, maka kesimpulan yang dapat ditarik dari penelitian ini adalah: Variabel Corporate Social Responsibility (CSR) memiliki pengaruh yang signifikan 
terhadap Nilai Perusahaan pada perusahaan yang terdaftar di Bursa Efek Indonesia.. Variabel Komite Audit (AC) dapat memoderasi hubungan Corporate Social Responsibility (CSR) terhadap Nilai Perusahaan (PER).

\section{Daftar Pustaka}

Anggraini, D. 2013. Pengaruh Good Corporate Governance, 2, 1-14.

Bayu, A. N., Putra, D., \& Wirakusuma, M. G. (2015). Pengaruh Pengungkapan Corporate Social Responsibility Pada Nilai Perusahaan Dengan Profitabilitas Sebagai Pemoderasi. Jurnal Akuntansi Universitas Udayana, 13(2), 2302-8556.

Berkelanjutan., G. R. I. 2013. G. G. 4-B. I. P.

Bursa Efek Indonesia. Laporan Keuangan. www.idx.co.id

Carcello, J. V., \& Neal, T. L. 2000. Audit committee composition and auditor reporting. The Accounting Review, 75(4), 453-467.

Cretu, A. E., \& Brodie, R. J. 2007. The influence of brand image and company reputation where manufacturers market to small firms: A customer value perspective. Industrial Marketing Management, 36(2), 230-240.

DeFond, M. L. dan Jiambalvo, J. 1994. "Debt Convenant Violation and Manipulation of Accruals". Journal of Accounting \&Ecconomics 17, hal. 145-176.

Freeman, R. E., Wicks, A. C., \& Parmar, B. 2004. Stakeholder theory and "the corporate objective revisited". Organization science, 15(3), 364-369.

Goold, M., Campbell, A., \& Alexander, M. 1994. Corporate-level strategy: Creating value in the multibusiness company. Wiley.

Gray, R., Kouhy, R., \& Lavers, S. 1995. Corporate social and environmental reporting: a review of the literature and a longitudinal study of UK disclosure. Accounting, Auditing \& Accountability Journal, 8(2), 47-77.

Jones, P. and Comfort, D. 2005, "Corporate Social Responsibility and The UK's Top Ten Retailers", International Journal of Retail Distribution Management, Vol. 33 No. 12, pp.882-892.

Klein, A. 2002. Audit committee, board of director characteristics, and earnings management. Journal of accounting and economics, 33(3), 375-400.

Latupono, S. S., \& Andayani, A. 2016. Pengaruh Corporate Social Responsibility Terhadap Nilai Perusahaan: Good Corporate Governance Variabel Moderating. Jurnal Ilmu dan Riset Akuntansi, 4(8).

Matten, D., \& Moon, J. 2004. Corporate social responsibility. Journal of business Ethics, 54(4), 323-337.

McWilliams, A., \& Siegel, D. 2000. Corporate social responsibility and financial performance: correlation or misspecification?. Strategic management journal, 21(5), 603-609.

Muliani, L. E., Yuniarta, G. A., AK, S., \& Sinarwati, N. K. 2014. Pengaruh Kinerja Keuangan Terhadap
Nilai Perusahaan Dengan Pengungkapan Corporate Social Responcibility Dan Good Corporate Governance Sebagai Variabel Pemoderasi. JIMAT (Jurnal Ilmiah Mahasiswa Akuntansi) Undiksha, 2(1).

Rahayu, S., Rahayu, S., \& ANDRI, A. 2010. Pengaruh Kinerja Keuangan Terhadap Nilai Perusahaan Dengan Pengungkapan Corporate Social Responsibility Dan Good Corporate Governance Sebagai Variabel Pemoderasi (Studi Empiris Pada Perusahaan Manufaktur di Bursa Efek Jakarta) (Doctoral dissertation, UNIVERSITAS DIPONEGORO).

Suaryana, A. 2005. Pengaruh komite audit terhadap kualitas laba. Jurnal Ilmiah Akuntansi dan Bisnis.

Surjadi, C., \& Tobing, R. L. 2016. GOOD CORPORATE GOVERNANCE TERHADAP NILAI PERUSAHAAN ( Studi pada PerusahaanPerusahaan Emiten yang Terdaftar Pada LQ 45 Periode Agustus 2014 s / d Januari 2015 ). Jurnal Manajemen Bisnis, 11(2), 69-78.

Tai, F. M., \& Chuang, S. H. 2014. Corporate social responsibility. Ibusiness, 6(03), 117.

Wahba, H., \& Elsayed, K. 2015. The mediating effect of financial performance on the relationship between social responsibility and ownership structure. Future Business Journal, 1(1-2), 1-12. https://doi.org/10.1016/j.fbj.2015.02.001 